\title{
editorial
}

\section{La Ley de Protección de Datos y la comunicación científica}

\begin{abstract}
$\mathscr{L}$ a comunicación oral o escrita, la presentación de casos clínicos y series de casos y el tratamiento de imágenes que hacen referencia al paciente, constituyen actividades de investigación o científicas que suponen un tratamiento de los datos personales del paciente, por lo que su ejecución se encuentra sometida a los principios que establece la legislación vigente en materia de protección de datos, en nuestro caso, la Ley Orgánica 15/1999, de 13 de diciembre, de protección de datos de carácter personal (LOPD), que realiza la transposición a nuestra legislación estatal de la Directiva 95/46/CE, del Parlamento Europeo y del Consejo, de 24 de octubre de 1995, relativa a la protección de las personas físicas en lo que respecta al tratamiento de datos personales y a la libre circulación de estos datos.

Para analizar en qué condiciones debe efectuarse ese tratamiento de datos, debe estudiarse el cumplimiento de cada uno de los principios que la LOPD establece para el uso de los datos que hacen referencia a una persona, haciendo especial incidencia en el de legitimidad de la finalidad perseguida y en el requerimiento de contar con consentimiento del interesado para poder tratar sus datos personales.
\end{abstract}

\section{LEGITIMACIÓN DE LA FINALIDAD}

La Ley 14/1986, de 25 de abril, General de Sanidad, establece en su artículo 6 que las actuaciones de las Administraciones Públicas Sanitarias estarán orientadas, entre otros supuestos, a "garantizar que cuantas acciones sanitarias se desarrollen estén dirigidas a la prevención de las enfermedades y no sólo a la curación de las mismas". Además, su artículo 18 indica como una de las actuaciones sanitarias del Sistema de Salud, "el fomento de la investigación científica en el campo específico de los problemas de salud". La misma Ley, establece en su artículo 61 que “... la información relativa a cada paciente ... estará a disposición de los enfermos y de los facultativos que directamente estén implicados en el diagnóstico y el tratamiento del enfermo, así como a efectos de inspección médica o para fines científicos, debiendo quedar plenamente garantizados el derecho del enfermo a su intimidad personal y familiar y el deber de guardar el secreto por quien, en virtud de sus competencias, tenga acceso a la historia clínica. Los poderes públicos adoptarán las medidas precisas para garantizar dichos derechos y deberes", y en su artículo 68, que "los centros hospitalarios desarrollarán, además de las ta- 
reas estrictamente asistenciales, funciones de promoción de salud, prevención de las enfermedades e investigación y docencia, de acuerdo con los programas de cada Área de Salud, con objeto de complementar sus actividades con las desarrolladas por la red de Atención Primaria".

Por su parte, la nueva ley 41/2002, de 14 de noviembre, básica reguladora de la autonomía del paciente y de derechos y obligaciones en materia de información y documentación clínica, establece los siguientes principios; su artículo 2, "la dignidad de la persona humana, el respeto a la autonomía de su voluntad y a su intimidad orientarán toda la actividad encaminada a obtener, utilizar, archivar, custodiar y transmitir la información y documentación clínica"; su artículo 7, "toda persona tiene derecho a que se respete el carácter confidencial de los datos referentes a su salud, y a que nadie pueda acceder a ellos sin previa autorización amparada por la ley"; y su artículo 16, "el acceso a la historia clínica con fines judiciales, epidemiológicos, de salud pública, de investigación o de docencia, se rige por lo dispuesto en la Ley Orgánica 15/1999, de Protección de Datos de carácter personal, y en la Ley 14/1986, de 25 de abril, General de Sanidad, y demás normas de aplicación en cada caso".

En conclusión, la Ley considera, como no podría ser de otra forma, que la docencia y la investigación constituyen dos actividades necesarias para el desarrollo de las actuaciones sanitarias que se atribuyen al Sistema de Salud, pero garantizando, en todo caso, el derecho del enfermo a su intimidad personal y familiar. La LOPD, consciente de la importancia de estas actividades, cuando indica en su artículo 4 que "los datos de carácter personal objeto de tratamiento no podrán usarse para finalidades incompatibles con aquéllas para las que los datos hubieran sido recogidos" las excepciona y dota de legitimidad, indicando que "no se considerará incompatible el tratamiento posterior de éstos (datos) con fines históricos o científicos".

\section{CONSENTIMIENTO DEL AFECTADO}

En el caso que nos ocupa, cualquier actividad de investigación o docencia desarrollada con los datos de un paciente obtenidos en la actividad asistencial debe tenerse en cuenta que estamos utilizando datos obtenidos del paciente para una finalidad muy concreta, su atención sanitaria y en unas determinadas condiciones, a un uso completamente diferente como es el de investigación o docencia, del cual no se ha informado expresamente al ciudadano y para el que no hemos recabado, en el normal de los supuestos, su consentimiento, y que aunque la normativa considere como actividad no incompatible, debe ajustarse al principio de consentimiento previo que establece la LOPD.

La Ley 41/2002, de 14 de noviembre, básica reguladora de la autonomía del paciente y de derechos y obligaciones en materia de informa- 
ción y documentación clínica, establece en su artículo 16.1 que “el acceso a la historia clínica con estos fines (de investigación o docencia) obliga a preservar los datos de identificación personal del paciente, separados de los de carácter clínico-asistencial, de manera que como regla general quede asegurado el anonimato, salvo que el propio paciente haya dado su consentimiento para no separarlos", abriendo dos posibles vías o modos de realizar estos trabajos; con datos disociados, cuando no sea posible asociarlos con una persona concreta, y con datos en los que aparece identificado de forma inequívoca el titular de esa información.

En el supuesto de disociación, la Ley establece el criterio de que la persona que pretenda acceder a los datos con fines científicos, no tenga acceso en ningún caso a aquellos datos que identifican al titular de los mismos, tarea que debe haberse realizado con carácter previo al acceso de los datos, de tal manera que la forma de almacenamiento de la documentación clínica distinga entre los datos identificativos y los clínicoasistenciales que figurarán en ficheros anónimos y que sólo el personal encargado de gestionar los archivos pueda relacionar cuando sea necesario. Cuando los datos que se utilicen respondan a estas características y sea imposible saber a quién corresponden los datos que se tratan, el tratamiento queda excluido del ámbito de aplicación de la normativa en materia de Protección de Datos (LOPD).

Cuando el tratamiento de los datos requiera conocer a quién corresponden, utilizando para ello los datos identificativos, será necesario el consentimiento inequívoco para tratar los datos del paciente con fines de investigación o docencia, circunstancia que se producirá cuando se cumpla la obligación de información previa que contempla la LOPD. Con carácter previo a la recogida de la información se debe informar al ciudadano de quién es el responsable de los datos que se están recabando y cuál es la finalidad a la que se van a destinar. Sólo cuando se cumpla este principio de información estaremos legitimados para poder realizar el tratamiento de los datos. Además, debe tenerse en cuenta que el consentimiento del interesado es revocable en cualquier momento y por cualquier causa, teniendo el titular de los datos la plena disponibilidad sobre los mismos.

También debe tenerse en cuenta que al tratarse de datos especialmente protegidos, tal y como los califica la LOPD, el consentimiento necesario tiene que tener la característica de ser expreso, no siendo suficiente en ningún caso cualquier tipo de consentimiento presunto o tácito. Para poder tratar datos referentes a la salud de las personas para fines distintos a los propiamente asistenciales, requeriremos una manifestación clara e inequívoca de voluntad del paciente que nos autorice a realizar el tratamiento de datos que pretendemos.

Dado todo lo anterior, para poder dedicar los datos obtenidos en el proceso asistencial a una tarea de investigación o docente, será necesario proceder a un procedimiento previo de disociación de los datos que 
impida el poder identificar a la persona a la que corresponden los mismos, u obtener su consentimiento expreso para tal uso, en cualquier otra condición el tratamiento será ilícito por incumplimiento de los principios que impone la LOPD. Este procedimiento de disociación, de acuerdo con la regulación de la Ley 41/2002, de 14 de noviembre, debe ser previo al acceso a los datos por la persona que va a realizar el trabajo de investigación o docencia, impidiendo que se acceda a los datos completos en tanto no conste la autorización expresa del afectado.

A. Igualada Menor Consultor Responsable del Área de Sanidad y Servicios Sociales. Agencia de Protección de Datos de la Comunidad de Madrid 